\title{
Assassin and Ninja:Several dimensions of cultural comparison between China and Japan Mingyang Liu
}

\author{
School of art and information engineering, Dalian University of industry Zip Code: 116103
}

\author{
Keywords: assassin; ninja; Sino-Japanese Culture
}

\begin{abstract}
Chinese culture is an important part of world culture and plays an active role in promoting the development and progress of world civilization. In Asia, most of the national culture are based on Chinese culture and extend in accordance with their own national conditions, Japan is a good example. Japanese culture is inherited from Chinese culture, but different from Chinese culture. This article will analyze and explore the Sino - Japanese culture from the two most mysterious angles of " assassin" and " ninja".
\end{abstract}

\section{Introduction}

China and Japan are neighbors, and the Chinese cultural background in Japanese is deep. The Japanese say “中国は日本の文化の母国である”（Chinese culture is the father of Japanese culture)

Under the influence of Chinese culture, the Japanese people constantly study and explore their own national, economic, political, military and other aspects of the characteristics, and finally form a " representative of the east" Japanese culture. In Japanese culture, " ninja" as a mysterious group of silence in the long historical process, its mysterious hidden behind the unique Japanese culture; In China, " assassin" has a long history, the most representative in the history of China " assassin" image is Jing Ke, "The desolating gale freezes River Yi,The doomed hero has made his death wish" assassin image spread from the Qin dynasty to the contemporary, from the assassin, also can reflect some Chinese culture. Although " assassin" and " ninja" is just a point in the Sino - Japanese culture, but as long as the in-depth analysis of this point, you can dig out valuable cultural information, so " assassin" and " ninja" deserves our attention.

2. Time background dimension: The background of "troubled times hero" promotes the formation of " assassin" and " ninja"

\subsection{The origin of the "assassin"}

During the Spring and Autumn Period and the Warring States Period, Chinese history has gone through the ages of the spring and autumn five hegemonies and the warring States seven hegemonies, in order to seek political development and realize the interests of individuals or groups, the " assassin" came into being under the background of the war. They each consider for their own owners, at the expense of life to help employers achieve the purpose of assassination.

" Assassin" is not " made in China", in the middle ages in Europe, assassin has become a more mature career, such as widely known single game " Assassin's Creed", it is in the context of European assassin culture. From the macro level, " Chinese assassin" is just a branch of " assassin"; from a micro perspective, it was difficult for cultures of different countries to intersect because of the influence of transport and communication technologies in ancient times. The " Chinese assassin" is a special occupation under the influence of Chinese culture, they are the " assassination tools" used by the top of society to satisfy individual interests.

\subsection{The origin of the "ninja"}

The "ninja" was first appeared in the Edo era of Japan, but the occupation of ninja dates back to the warring States period from the 14th century to the end of the 15th century.[2] The warring States period of Japan is similar to China, in the background of the Warlords Rivalry age, only the ambitious person can be king, in order to expand their sphere of influence, governors of various 
countries began to employ professionals with special skills to complete complex activities such as information gathering and assassination, ninja was born under the background of war. The " ninjas" have superior skills and good at patience, they all have the ability to " one man beat one hundred men", they are more frequent activities in the war. When entering the more stable and peaceful period of the Tokugawa family rule, they basically disappeared, as a hermit hidden deep in areas that are not easy to detect.

From the perspective of the background of the times, " assassin" and " ninja" are produced in the war period, their activity enthusiasm is positively correlated with the complexity of the domestic situation, they move more frequently in complex domestic situations and significantly reduce their frequency in a stable and peaceful environment.

\section{Cultural dimension: the Sino - Japanese culture behind the "assassin" and "ninja"} 3.1 "Assassin" style with Chinese traditional culture characteristics

" Assassin" is low - key, like a cup of water, colorless and tasteless, ordinary people can't detect any information, but as long as the opportunity exist, even if it is very small, they will be in a " fatal blow" way to complete their mission. "Assassins" who take "assassination" as their profession have the possibility of being exposed and killed at any time, but with absolute loyalty and adherence to their own "professional ethics", the task is the whole of life. From the "assassin," we can see the traces of "blind loyalty" in Chinese traditional culture, although these assassins know that they are just a pawn in the hands of politicians, but by limited of the " assassin" professional ethics, accepting a task is tantamount to choosing to undertake, and choosing to undertake is bound to be life-threatening, this is the fundamental characteristics of the " assassin" occupation. With the passage of time, in the development and change of history, they formed the style characteristic of "blind loyalty", but the blind loyalty of the " must be distinguish with " Yue Fei" and other " national star", the former is "blind loyalty" held hostage by professional ethics, while the latter is "blind loyalty" under the influence of traditional Confucianism.

\section{2 "Ninja" style with Japanese characteristics}

Compared with fighting skills, " ninja" pay more attention to cultivation, emphasize " forbearance", this is completely different from Chinese" assassin", the latter's " sacrifice justice" behavior is only to practice " professional ethics", and the former's " ignore the life and death" is the inevitable result of personal cultivation. " Ninja" as the theme of the film is popular with the audience, on the one hand, most of them are action films, which are in line with the interests of most people, on the other hand, it opened the mysterious veil of " ninja" at a certain level, to achieve the effect of " answering questions and solving puzzles". The image that ninjas give us is mysterious, in addition, is "never give up until achieve the goal.", even if "I would never change my first intention no matter how many people I have to fall into conflicts against." they are also "will not refuse under any circumstances", they pay great attention to the famous festival, once the action fails, they usually in the form of abdominal suicide to protect their reputation. These characteristics of "ninja" directly reflect the traditional culture of Japan, even in contemporary times, this culture still exists, that is, the " gratitude" and " shame" culture.

During World War II, Japanese soldiers were cruel and inhuman, but also kept the spirit of "always willing to die for the emperor", so they would not consider the proposition "whether they can survive or not" during the war. In 1945, after hearing the emperor's declaration of surrender, Japanese who were so fierce and eager for war surrendered one after another. When MacArthur, the commander of the US military, entered Japan and talked about the conditions of surrender, he was welcomed by the Japanese people. Even some Japanese soldiers don't complain too much about the Americans, the arch-rivals of World War II, and we find that there seems to be some contradiction between Japan's attitude to war and defeat, but from the Japanese perspective, this is very normal, because of the "gratitude" culture. It is generally believed in Japan that everything they have is due 
to the gift of the emperor, for this reason, they have a culture of gratitude in the depths of their souls and it is their duty to serve the emperor. When the emperor said to fight, the Japanese rushed to the battlefield regardless of everything, the emperor said to surrender, and the Japanese surrendered one after another. They don't care about the gain and loss of the war, but paid attention to whether can realize the " gratitude", this kind of deep-rooted concept also exist in Japan today.

" Ninja" does not regard their activities as a career, but they think that the " ninja" course is spiritual practice, which is completely different from the professional concept of "assassin". Influenced by the " gratitude" culture, " ninjas" serve only those who give favor to themselves, the essence of their activities is not to gain benefits, but to " gratitude", at the same time, " ninja" pay attention to the " shame culture", they believe that what they do will not fail, once they encounter failure in the execution of " trusted" assassination, intelligence gathering and other activities, they will think that they have failed to live up to the expectations of others, their limited ability affected their reputation, and they will choose to commit suicide to maintain the prestige of their reputation. The "shame" culture of "ninjas" still exists in today's society, and World War II is a good example. The reason why the Japanese do not recognize the aggressiveness of war lies in the Japanese "shame" culture. The Japanese generally know that the war itself is unjust, but if they admit the unjust nature of war, The Japanese people would be humiliated, so they would rather "risk universal condemnation" than refuse to recognize the aggressiveness of war.

\section{Fatalistic dimension: the act of sacrificing others for survival ends with destruction}

Whether "assassin" or "ninja", whether "blind loyalty under the influence of professional ethics" or "pay attention to the loyalty of the gratitude culture", they are all acts of sacrificing the interests of others, or even of their lives, in exchange for their own survival and development, so when it comes to the end, they all perish and ruin, especially in the times of peace, they will gradually be marginalized with the development of society, and eventually disappear somewhere in the world. The fatalism of "assassin" and "ninja" has a direct relationship with the culture of "good will be rewarded with good and evil with evil ", which is emphasized in the traditional culture of China and Japan, "make haste in doing good" is the cultural factor that the two countries carry out together.

\section{Conclusion}

The Japanese have a culture of martial culture since ancient times, and almost every aspect is influenced by Bushido culture and ninja spirit. It affects and will continue to affect the Japanese from generation to generation.[ 3 ] With the help of Japan's " ninja" research and China's " assassin" exploration, we can find the similarities and differences between the two cultures, in order to promote our culture and economy to achieve the development goal of " good and fast".

\section{References}

[1] Hu Ping, Tu Yaling. Comparison and analysis of cultural differences between China and Japan.

[J]. Intelligence, 2011(05): 225.

[2] Zhang Fan, Peng Shiyu. Assassin and Ninja: Several dimensions of cultural comparison between China and Japan. [J] .English Square, 2016(07):70-73.

[3] Zhang Xin, He Ping, Xiao Kao, Li Xiaoyu.Influence of ninja spirit on Japanese national character. [J] . Journal of Guangxi Vocational and Technical College, 2010,3(04):73-75. 